\title{
Erratum
}

\section{Multiple sclerosis: getting personal with induced pluripotent stem cells}

\author{
A Di Ruscio, F Patti, RS Welner, DG Tenen and G Amabile
}

Cell Death and Disease (2016) 7, e2185; doi:10.1038/cddis.2016.59; published online 14 April 2016

Correction to: Cell Death and Disease (2015) 6, e1806; doi:10.1038/cddis.2015.179; published online 9 July 2015

Since the publication of this paper, the publisher has noticed that the Open Access license is missing.
The corrected article appears online together with this erratum.

The publisher would like to apologize for any inconvenience caused. 